\title{
LEGISLATIVE MEANS AIMED AT STIMULATING GREEN PROCUREMENT IN THE PUBLIC SECTOR. A GRITICAL GASE STUDY OF ROMANIA
}

\author{
Ionel Bostan ${ }^{1 *}$, Cristina Mihaela Lazăr ${ }^{2}$ and Nicoleta Asaloș ${ }^{3}$ \\ ${ }^{1)}$ Stefan cel Mare University of Suceava, Romania \\ ${ }^{213)}$ Ovidius University of Constanta, Romania
}

\begin{abstract}
Please cite this article as:
Bostan, I., Lazăr, C.M. and Asaloș, N., 2020. Legislative Means Aimed at Stimulating Green Procurement in the Public Sector. A Critical Case Study of Romania. Amfiteatru Economic, 22(53), pp. 221-238.
\end{abstract}

\section{Article History}

Received: 29 September 2019

Revised: 24 November 2019

Accepted: 28 December 2019

DOI 10.24818/EA/2019/53/221

\begin{abstract}
In a framework characterized by a relatively high degree of institutionalization, such as that of the European Union, it became difficult to imagine that the problem of Green Public Procurement (GPP) could surpass it. The special importance of the GPP, due to its favorable effects on the sustainable development, conservation / improvement of the environment, human health, etc., to which other positive social-economic implications are added, makes it a distinct subject of both EU strategies / policies, and the related legislative system. In this respect, several directives, decisions and recommendations operate, which have obviously made a strong imprint on the policies and legislation of the Member States. Starting from the European requirements in the field, but also taking into account the regulatory framework applicable in Romania, our approach tackles legal instruments designed to stimulate GPP in the public sector, highlighting the dysfunctions in the field of green procurement special legislation. We consider here some delays in the application of the European legislation and related to the appearance of the guide containing the minimum criteria regarding environmental protection, etc., but also the existence of loopholes or contradictions in the legislative texts, as well as post-adoption deadlocks. In order to achieve the purpose of the paper, which is to demonstrate that the legislative means are capable of stimulating green procurement in the public sector, we carry out a review of the scientific literature, after which we focus on the European legislative system related to GPP. We then insist on the elaboration and implementation of national legal instruments aimed at stimulating the GPP and the arguments for strengthening the GPP system by regulatory means. Lastly, we saved an important part, that of the description of the special legal source intended to regulate the GPP in the national public sector, which is characterized by sluggishness, loopholes, post-adoption deadlocks. Our approach, in the structure shown, demonstrations that the regulatory body regarding the Romanian GPP system is characterized by inefficiency. According to the authors, the solution is implementing some legislative changes, strictly in accordance with the best European practices.
\end{abstract}

Keywords: green public procurement; regulatory system; legal loopholes; sanctions; inefficiency/inoperative law

JEL Classification: K32, K39, Q56, Q59, R11.

*Corresponding author, Ionel Bostan - ionel_bostan@yahoo.com or ionel.bostan@ fdsa.usv.ro 


\section{Introduction}

In the current global and - especially - European context, when the issue of real and sustainable protection of the environment is gaining importance, becoming the subject of state policies in most countries of the world, we consider that any topic related to arguing the need for the expansion of green public procurement (GPP) deserves to be treated primarily. In fact, the publisher's initiative to open such a topic to the debate of Romanian and foreign researchers is more than commendable, if we only think about the fact that, as important as this is, in Romania - but also in the world - we consider that the progress made is far below the possibilities of the society.

We recall that, unanimously, green public procurement, or to put it simply - green public procurement, is, in fact, "a process by which public authorities want to purchase goods, services and works with a low impact on the environment, during their entire life cycle, compared to the goods, services and works with the same primary function purchased other than through green public procurement" (European Commission, 2008).

After a comprehensive review of the scientific literature, our approach tackles the legal instruments designed to stimulate green procurement in the public sector (other contracting entities / authorities are added, under certain conditions established by the law, even if they are, in fact, subject to private law), starting from the European requirements in the field, but then focusing on the regulatory framework directly applicable to GPP in Romania.

Since we have intended this paper to be a critical study on the mentioned topic, the second part is dedicated to the analysis of the special legislation on GPP at the national level, a context for us to reveal several deficient aspects. Furthermore, we bring to the fore some elements regarding the European legislative framework applicable to GPP, the elaboration and implementation of national legal instruments aimed at stimulating GPP, the arguments for strengthening the GPP system by normative means and characterizing the special legal source intended to regulate GPP in the national public sector.

With strict reference to Romania, we show that although theoretically there has been a special law for over three years, dedicated to the regulation of GPP, which - among others - compels the elaboration of a National Plan in this respect, with concrete objectives, but also to "the introduction in the process of public procurement of environmental protection criteria that would allow the improvement of services' quality and optimization of costs with public procurement in the short, medium and long term" (Government of Romania, 2014), the achievements regarding GPP today are rather modest. Obviously, the nonperformance in the mentioned area are not due exclusively to the legislative deficiencies, however, based on the studies undertaken, we can say that a rethinking of the legal norms pertaining to the GPP field, in accordance with the best European practices, is meant to lead to the attainment of some higher performance thresholds in the direction shown.

\section{GPP approaches in the circular economy context}

Worldwide, this type of procurement is mentioned for the first time in the Plan of Implementation of the World Summit on Sustainable Development (held at Johannesburg, in 2002), which aimed to "promote public procurement policies that encourage the development and commercialization of goods and services that comply with environmental standards" (WSSD, 2002). 
In fact, the entire discussion about GPP, in regards to environmental benefits, derives from the differences that appear in terms of practicing the circular economy (minimal waste, because it aims to maintain resources in the economic system through modernization / resale / reuse as by-products) compared to the linear economy (Figure no. 1).

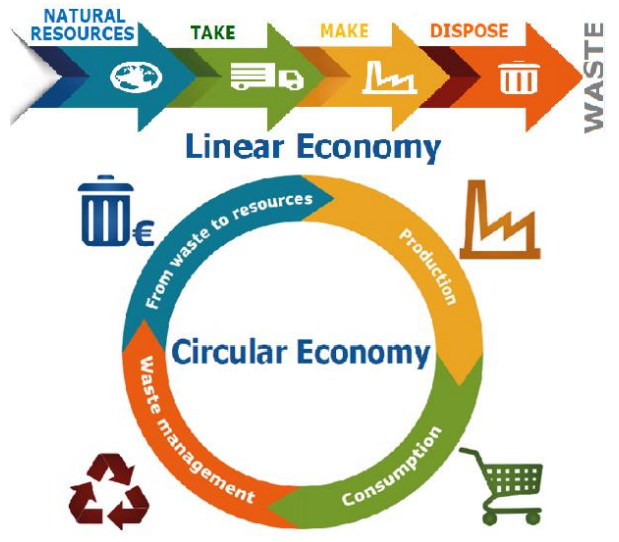

Figure no. 1: Diagram of differences between Linear economy and Circular economy

Source: Authors' adaptation after Kaukewitsch, 2018

Subsequent to the "Johannesburg" (2002) moment, Organization for Economic Co- operation and Development (OECD) Member States adopted the Council's Recommendation "to improve the ecological performance of public procurement" (OECD, 2002), and afterwards the landscape of international law regulations in this field would gain more consistency.

With regard to the issue of the real involvement of the EU Member States in the introduction of the circular economy, after the adoption of the act "Public procurement for a better environment (European Commission, 2008), we consider the data in Table no. 1 to be edifying, reflecting a "Member States' division between three broad bands, based on a ranking according to the implementation of the National Action Plans, GPP and circular economy" (ECAP/European Clothing Action Plan, 2018).

According to the same source, observing Table no. 1, the following can be emphasized: (i) many more countries must start the constant implementation of GPP actions and the circular economy or the use of public procurement as a strategic tool for encouraging circularity (Band 3); (ii) some countries implement GPP to some extent, but are not strictly connected with the circular economy (Band 2); some countries are now beginning to simultaneously implement GPP and the circular economy (Band 1).

The motivation for the implementation of the green public procurement policies is becoming clearer than ever, being related to the medium and long-term benefits regarding the environment, the adoption and implementation of this type of procurement (Bauer et al., 2009). 
Table no. 1: Division between the EU Member States according to the implementation of the National Action Plans, GPP and circular economy

\begin{tabular}{|c|c|c|c|}
\hline & Band 1 & Band 2 & Band 3 \\
\hline Definition & $\begin{array}{l}\text { Evidence of active CE } \\
\text { and sustainable } \\
\text { procurement } \\
\text { implementation; some } \\
\text { evidence of circular } \\
\text { procurement pilots }\end{array}$ & $\begin{array}{l}\text { Partial implementation of } \\
\text { NAPs, some sustainable } \\
\text { procurement } \\
\text { implementation and CE } \\
\text { package actions }\end{array}$ & $\begin{array}{l}\text { Insufficient availability } \\
\text { and/or implementation } \\
\text { of NAP, GPP and } \\
\text { sustainable } \\
\text { procurement. Low } \\
\text { implementation of CE } \\
\text { package measures }\end{array}$ \\
\hline Countries & $\begin{array}{l}\text { Austria, Belgium, } \\
\text { Denmark, Finlanf, } \\
\text { France, Ireland, Italy, } \\
\text { Netherlands, Portugal, } \\
\text { Sweden, United } \\
\text { Kingdom }\end{array}$ & $\begin{array}{l}\text { Bulgaria, Germany, } \\
\text { Latvia, Malta, Spain }\end{array}$ & $\begin{array}{l}\text { Croatia, Cyprus, Czech } \\
\text { Republic, Estonia, } \\
\text { Greece, Hungary, } \\
\text { Lithuania, } \\
\text { Luxembourg, Poland, } \\
\text { Romania, Slovakia, } \\
\text { Slovenia }\end{array}$ \\
\hline $\begin{array}{l}\text { Development } \\
\text { options }\end{array}$ & $\begin{array}{l}\text { Strategic procurement; } \\
\text { category management } \\
\text { voluntry sectoral } \\
\text { commitments (e.g. } \\
\text { 'green deal' type); link to } \\
\text { broader CE; } \\
\text { certification\&labelling } \\
\text { developing additional } \\
\text { circular textiles criteria }\end{array}$ & $\begin{array}{l}\text { Strategic procurement; } \\
\text { category management, } \\
\text { piloting circular textiles, } \\
\text { GPP comprehensive } \\
\text { criteria, Adoption of } \\
\text { circular national criteria, } \\
\text { guidance\&capacity } \\
\text { building in circular } \\
\text { procurement }\end{array}$ & $\begin{array}{l}\text { Consistency in use of } \\
\text { GPP criteria for } \\
\text { textiles, piloting } \\
\text { textiles as category } \\
\text { approach, capacity } \\
\text { building in sustainable } \\
\text { procurement and } \\
\text { circular economy }\end{array}$ \\
\hline
\end{tabular}

Source: ECAP, 2018

In a nutshell, the products / services purchased under this system are exclusively capable of removing / diminishing the negative effects on the environment, but also human health, etc., to which other economic implications are added (Figure no. 2).

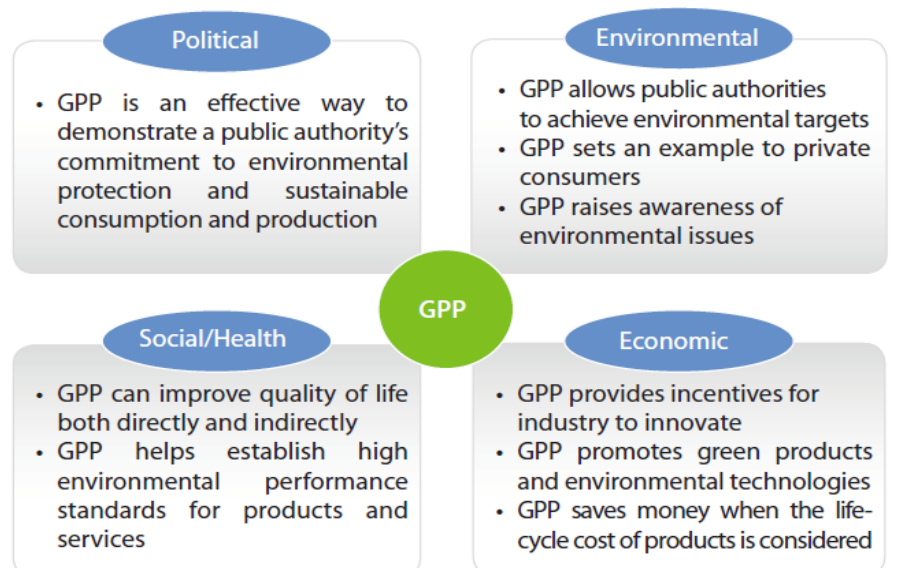

Figure no. 2: The advantages of green public procurement (GPP)

Source: European Comission, 2010 
As for the EU area, given the high GPP purchasing power (aiming at 2000 billion Euros), the European Commission is actively supporting "a greater use of public procurement as a strategic instrument to support the environment" (European Commission, 2019).

The fact that a considerable proportion of the financial resources involved is constituted in investments in transport, infrastructure, etc., leads to the interpretation that, without a doubt, GPP is meant to massively support the sustainable type of innovative companies.

\section{Review of the scientific literature}

An analysis of the specialized literature focused on GPP issues considered the most representative works published in the last years. What we find is that in terms of theory and importance of GPP, it is treated and documented as well as possible (Cheng et al., 2018). The idea that "green procurement could achieve sustainable development goals through the procurement and supply process should consider at least four aspects: moving from an ecological approach to the social and economic dimensions, sustainability and innovation, ethical procurement and quantification issues" (Xu et al., 2016) seems to be quasi-accepted.

A first observation on the respective literature is that if some authors address the problem theoretically or globally (Testa et al., 2016a; Igarashi et al., 2015), others address the problems at national / regional / division level (Walter and Brammer, 2009; Michelsen et al., 2009; Varnäs et al., 2009; Fuentes-Bargues et al., 2019; Zhu et al., 2013; Tessema and Marsille, 2009; Preuss, 2009; Appolloni et al., 2014; Aldenius and Khan, 2017; Smith and Terman, 2016), so that, finally, some give their publications important international accents (Brammer and Walker, 2011; Nissinen et al., 2009).

In any case, the study of the works to which we refer here reflects a good crystallization in terms of specific theory and concepts, differing only in terms of the view on the priorities that are mandatory or the modalities of implementation. The common element of the respective works is that this type of procurement, due to the advantages encompassed in the plan of a healthy and sustainable environment, must be strongly encouraged, using any means allowed / provided by the legislative system. Even when it comes to certain evaluation methods or impact determinations regarding GPP, we find valuable works (Shengguo et al., 2016; Oruezabala and Rico, 2012).

A particular approach is the one according to which the GPP issue is debated in the context of the economic crisis (Nikolaou and Loizou, 2015), when the inherent difficulties are analyzed (Testa et al., 2016b; Thomson and Jackson, 2007), or when the context of the socio-technical transition is considered (Trindade et al., 2018). In the latter paper it is shown that "The development of inter-organizational factors, which underlie the formation of the niche, was still in an initial phase, corresponding to the initial creation of social networks. The expectations and visions, as well as the learning process, would need much more development, so as to ensure a successful trajectory and influence the respective regime" (Trindade et al., 2018).

However, some issues in the area of our discussion - such as those related to assessments, indicators, determining the real impact (direct / indirect), etc. - have not yet found comprehensive solutions (Lundberg and Marklund, 2017; Lundberg et al., 2016), demanding the researchers to insist on them until a full edification. 
Regarding approaches like the one we have taken - from a legislative perspective, the specialized literature is far from vast. However, we can note from the works consulted that the issue of normative instruments with an impact on this type of procurement has been a matter of concern for some valuable authors in the field (Davies, 2011; Palmujoki et al., 2010).

Suitable presentations from the European law's point of view can be found in the case of the Swedish authors Sofia Lundberg and Per-Olov Marklund (2013), who, besides the norms presented in a remarkable manner, also refer to the practices, models and instruments circumscribed to the GPP issue, as well as the Slovak author Tomáš Malatinec (2017). At the European level, the work of Roberto and Trybus is of chief importance (2010), in addition to those written by Ajani (2008), Arrowsmith and Kunzlik (2009), Bovis (2007) and McCrudden (2007).

Regarding some benchmarks of the local specialized literature, a study on this topic notes that although "the environmental aspect of sustainability is essential in the field of public procurement (...)", "the protection of the environment through public procurement is a little studied phenomenon in Romania" (Cazan, 2014). Moreover, we note that the study itself is a "comprehensive analysis of the national and community framework regarding the possibility for public institutions to consider environmental issues in public procurement and deliver results related to sustainable development from an environment protection perspective" (Cazan, 2014).

Other Romanian authors' works we have consulted (Preda and Popescu, 2019; Preda and Simion, 2019; Leica et al., 2017; Dacian and Neamtu, 2014; Giurca and Giurca, 2010) tackle the GPP issue from different angles, the legislative component or some common principles, rules and standards, which can be found in different proportions.

\section{The European legislative framework applicable to ecological/green public procurement}

The fact that, at the level of the European Union, sustainable development represents a fundamental purpose (European Commission, 2007), being included in the constitutive acts (i.e. the 1997 Treaty), has gained maximum notoriety. Deriving from its importance, the "environment pillar" was added to other important points of the Lisbon Strategy (Commission of The European Communities, 2005), following the adoption of the EU Sustainable Development Strategy by the Göteborg European Council (2001). Obviously, the context of setting and achieving high economic objectives, correlated with the special concerns for environmental protection (Bostan et al., 2010) (i.e., after the ratification of the Kyoto Protocol of 2002 on climate change, EU committed to reducing greenhouse gas emissions, compared to 1990 levels, by $8 \%$ between 2008-2012), also created the institutional framework regarding green procurement.

About GPP, even earlier (2001), the European Commission had already established "the possibilities offered by EU law to integrate environmental considerations into public procurement procedures" (European Commission, 2001). However, the Public Procurement Directives would be adopted three years later (European Parliament, 2004a, 2004b), only since then did EU countries have concrete legal instruments, designed to provide some solidity to the respective institutional context.

Thus, we find here formulas applicable in the case of including some environmental considerations in the selection criteria of the technical specifications and of the awarding, 
as well as in the procurement contract, through the execution clauses. As one can guess, the respective European legal instruments aimed since the very beginning the transactions of significant values in the EU space, however, later, certain principles under which green public procurement is also included- the free movement of goods, the freedom of establishment and provision of services, equal treatment, transparency, etc. - determined the EU Court of Justice to decide that the provisions of the respective Directives also apply in the case of procurement contracts which involve amounts below the established limits.

Among the other official EU documents of maximum relevance in the GPP plan, which intervened in the institutional system targeted after the adoption of the Public Procurement Directives of 2004, we find the complete series of directives: 2014/23/EU, 2014/24/EU and 2014/25/EU (European Commission, 2016a). They were intended to bring all the necessary clarifications regarding the application of the norms and principles aimed at stimulating the GPP, while presenting many opportunities for those interested.

After their adoption, any public procurement takes into account strictly the provisions of the Agreement with the World Trade Organization (WTO) on fair international competition for public contracts, as well as the basic principles of the EU Treaty (equal treatment, nondiscrimination, transparency and proportionality), regardless of the value of the contract. In this regard, we consider that the diagram below (Figure no. 3 ) is very eloquent.

\begin{tabular}{|c|c|c|c|}
\hline \multirow{3}{*}{$\begin{array}{l}\text { Product } \\
\text { Life-cycle } \\
\text { Technical specifications } \\
\text { and award criteria may } \\
\text { refer to any stage of a } \\
\text { product lifecycle, } \\
\text { including addressing } \\
\text { specific production } \\
\text { practices, provided that } \\
\text { they are linked to the } \\
\text { subject-matter of the } \\
\text { contract and } \\
\text { proportionate to its value } \\
\text { and its objectives. }\end{array}$} & \multirow{5}{*}{$\begin{array}{l}\text { Product labels } \\
\text { Product labels can be } \\
\text { required as means of proof in } \\
\text { technical specifications, } \\
\text { award criteria or contract } \\
\text { performance conditions as } \\
\text { long as all the underlying } \\
\text { criteria of the label are linked } \\
\text { to the subject matter of the } \\
\text { contract. } \\
\text { - The label must also meet } \\
\text { specific criteria defined in the } \\
\text { Directive regarding } \\
\text { transparency, objectivity, } \\
\text { accessibility, and credibility. } \\
\text { - Bidders must supply the } \\
\text { named label or an equivalent } \\
\text { label unless they can provide } \\
\text { a convincing argument as to } \\
\text { why they were not able to }\end{array}$} & \multirow[t]{2}{*}{$\begin{array}{l}\text { Social impact } \\
\text { Social impacts throughout } \\
\text { a product's lifecycle, such } \\
\text { as fair trade criteria, are } \\
\text { explicitly allowed to be } \\
\text { addressed by award } \\
\text { criteria. For technical } \\
\text { specifications the legal } \\
\text { position is less clear, with } \\
\text { different interpretations } \\
\text { presented. }\end{array}$} & $\begin{array}{l}\text { MEAT } \\
\text { Use of most economically } \\
\text { advantageours tender' } \\
\text { (MEAT) as default criteria. } \\
\text { When transposing the } \\
\text { Directives, member states may } \\
\text { choose to forbid or restrict the } \\
\text { use of lowest price as the sole } \\
\text { award criterion. }\end{array}$ \\
\hline & & & \multirow{3}{*}{$\begin{array}{l}\text { Verification } \\
\text { Introduction of a European } \\
\text { single procurement document } \\
\text { for bidders. This makes it } \\
\text { easier to verify and standardise } \\
\text { any proofs of environmental } \\
\text { and social compliance given } \\
\text { by bidders. }\end{array}$} \\
\hline & & \multirow{4}{*}{$\begin{array}{l}\text { Subcontracts } \\
\text { Possibility for greater } \\
\text { control over } \\
\text { subcontracting practices: } \\
\text { the contractor is obliged to } \\
\text { disclose the expected level } \\
\text { of subcontracting in } \\
\text { advance as well as } \\
\text { providing, in the case of } \\
\text { works and services } \\
\text { contracts, contact details } \\
\text { and details of legal } \\
\text { representatives of any } \\
\text { company used as a } \\
\text { subcontractor. }\end{array}$} & \\
\hline \multirow{3}{*}{$\begin{array}{l}\text { Life-cycle } \\
\text { Costing } \\
\text { The use of Life cycle } \\
\text { costing (LCC) as a } \\
\text { method for assessing } \\
\text { tender costs is clarified. } \\
\text { Contracting authorities } \\
\text { may select to include } \\
\text { costs imputed to } \\
\text { environmental } \\
\text { externalities in this } \\
\text { calculation. }\end{array}$} & & & \\
\hline & & & \\
\hline & \multirow{2}{*}{$\begin{array}{l}\text { ILO labour standards } \\
\text { ILO Labour standards are } \\
\text { now explicitly mentioned in } \\
\text { the introductory recitals, } \\
\text { giving them greater } \\
\text { prominence, Child labour and } \\
\text { human traffickong are also } \\
\text { specifically included as } \\
\text { grounds for exclusion. }\end{array}$} & & \\
\hline $\begin{array}{l}\text { externailties in this } \\
\text { calculation. }\end{array}$ & & & \\
\hline
\end{tabular}

Figure no. 3: Elements from the GPP domain made possible by the adoption
of the 2014 Directives (2014/23/EU, 2014/24/EU and 2014/25/EU)

Source: European Commission, $2016 \mathrm{~b}$

As shown in this section of our approach, the European legal system sanctions a whole series of principles and norms that need to be fully respected when awarding public procurement contracts. 
Essentially, the provisions of the directives invoked "explicitly allow the use of ecological specifications when defining the requirements, if: the respective specifications - obligatory accessible to all interested parties - are adequate for defining the characteristics of the products concerned; label requirements are based on scientific information; ecological labels are adopted with the participation of all stakeholders - government bodies, consumers, producers, distributors and environmental protection organizations" (Giurca and Giurca, 2010).

Our examination has confirmed that based on the European legislative framework applicable to green public procurement, to which we referred briefly, there is an extremely wide range of ways to also implement the very important environmental objectives.

\section{Elaboration and implementation of national legal instruments aimed at enhancing GPP}

\subsection{Green public procurement in Romania - a brief critical look}

At national level, there is, for over three years a special law dedicated to the regulation of GPP. Acting in correlation / corroboration with other normative acts, it can be considered to generate counterproductive bureaucracy. Indeed, in general, the public procurement process is characterized as a complicated one, often unnecessarily involving multiple procedures, stages and fixed deadlines, unjustified litigation deadlocks, etc., which is mainly due to the complex set of national norms.

Consequently, given the public procurement legislative framework (Government of Romania, 2006), it is obvious that the GPP process also entails certain difficulties in its implementation. A picture of this type of process' development is suggested in Figure no. 4.

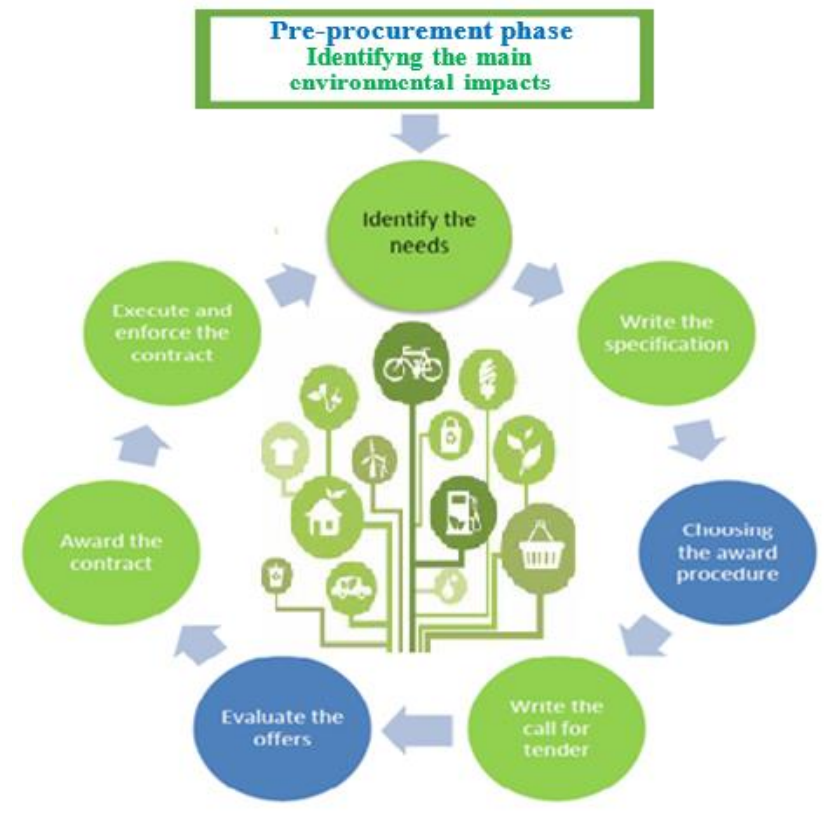

Figure no. 4: Development of the process of green public procurement

Source: Authors' adaptation after Staropoli, 2017 
Then, even if - on the other hand - the responsibilities of the competent authorities on the implementation and control of the implementation of the provisions of the GPP law have been clearly established, the respective system is clearly marked by the sluggishness regarding its effective implementation.

Furthermore, the National GPP Action Plan is not yet developed and published, which is common to several EU countries (Figure no. 5).

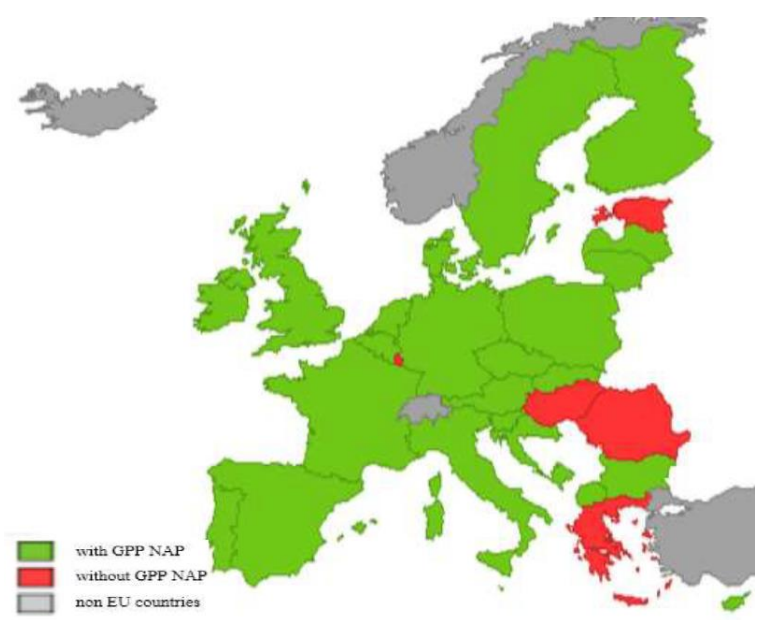

Figure no. 5: EU Member States with / without a National GPP Action Plan

Source: Malatinec, 2017

In the drafting phase of this Plan (2018-2019), Romania being clearly only in the (1) stage of preparation of the GPP system (Figure no. 6), the public releases of the Ministry of the Environment reflect its intention to establish the rule that "all state institutions be compelled that part of the annual purchases belong to the green category, the first figures aiming at a target of $5 \%$ for central institutions and $2 \%$ for territorial public institutions" (Călinoiu, 2018).

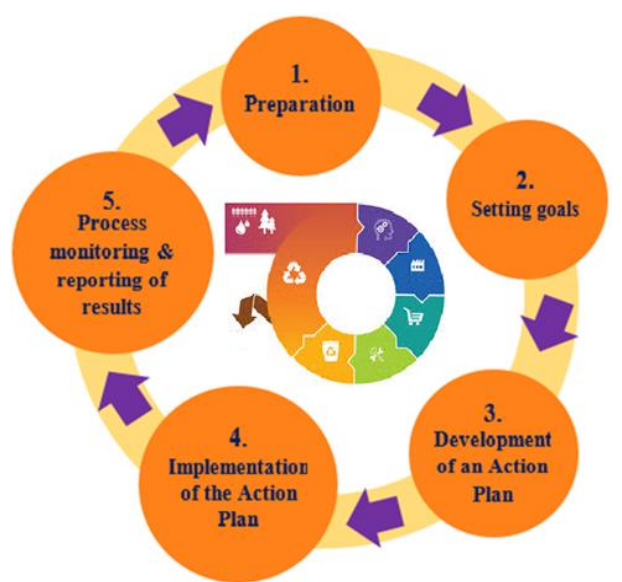

Figure no. 6: The GPP management model ("Deming" Cycle)

Source: Authors' adaptation after European Commission, 2009 
In the same context, it should also be noted that, in the way the normative preparations are presented, the failure to meet the targets set for the goods in the "first emergency" category (food / catering, cleaning products, furniture, office supplies, IT and stationery) would imply the imposition of sanctions by the National Agency for Procurement (ANAP) against the procuring entities / contracting authorities.

\subsection{Arguments for strengthening the GPP system through normative means}

As an EU Member State, by virtue of the legislation that governs the discussed issue, Romania is effectively involved in actions aimed at achieving objectives set in the New 2030 Agenda for sustainable development. This important document, in accordance with the ones established by the United Nations Resolution "Transforming the world we live in", adopted by the UN in September 2015, sets goals for sustainable development, consisting in ensuring sustainable consumption and appropriate production models, the transition to a greener economy etc., also favoring the implementation of GPP, considered an additional tool for the efficient use of resources (ONU, 2015).

Recent attitudes towards the circular economy reflect the Commission's commitment to supporting a better implementation of GPP criteria and rethinking the way GPP could be more extensively used across the EU, particularly for the products or markets that have a considerable relevance to the circular economy (MSDEC, 2018). In this regard, the signal given by the EU leadership on GPP regulation is significant: "we must go in the direction of green public procurement and many Member States are doing it, some better than others. If we consider the rules that are imposed from above (top-down), we must be very careful. Any such proposal in a Member State must have political support because otherwise it would obviously make no sense. We must carefully consider the extent to which a law on public procurement is possible or not" (Potočnik, 2016).

Indeed, it is known that EU GPP policies "encourage Member States to take additional measures in order to apply green public procurement criteria to at least $50 \%$ of public tenders" (European Commission, 2019).

In Romania, certain legal provisions supporting GPP were adopted more than ten years ago. When considering them, among the Romanian specialists we find the opinion that "among the major obstacles to the effective implementation of GPP is the elaboration of the relevant legislation in too broad terms giving the contracting authorities a wide range whether to act or not" (Cazan, 2014). The idea persists even after the adoption of the Law on green public procurement (2016), because all the development possibilities should have been considered, according to the model of the countries that have performed well in this field - the contribution to the protection of the environment, the expansion of the market with environmentally friendly products / services, etc.

Let us see how the problem presented itself three years ago, when it became urgent in Romania to adopt a GPP law. From the beginning, against the background of the intention of reducing the greenhouse gas emissions by cutting the amount of $\mathrm{CO}_{2}$ emitted into the atmosphere, the stated purpose was "to elaborate a National GPP Action Plan with precise annual targets and to introduce the environmental criteria into the process of public procurement" (Parliament of Romania, 2015).

Firstly, the concept of "green public procurement" was defined, namely that process "by which the contracting authorities use environmental protection criteria that allow the 
improvement of the quality of the services and the optimization of the public procurement costs in the short, medium and long-term" (Parliament of Romania, 2015).

Then, reference is made to the legal framework related to the GPP system at the European Union and national levels, taking into account the fact that, according to the European Commission, this concept "consists of using clear, verifiable, justifiable and ambitious environmental criteria for products and services, based on a life cycle approach and on scientific evidence" (European Commission, 2008).

The national legal framework related to the GPP system was extremely limited at that time, consisting of: (i) the National Strategy for sustainable development, horizons 2013-2020 2030 (Government of Romania, 2008) and the Emergency Ordinance which regulated the awarding of public procurement contracts (Government of Romania, 2006). Before stating the expected changes, one should mention that the chapter "Environment" of the Government Program 2013-2016 (Parliament of Romania, 2012) contains some commitments regarding GPP, among which their encouragement by adopting a specific action plan, aimed at "promoting the models of sustainable production and consumption", the development of clean and environmentally friendly technologies, the elaboration of efficient criteria for GPP, not forgetting the need to inform / raise the awareness of the authorities in the same field.

Regarding the expectations on the adoption of such a normative act, they are related to the fact that, with the establishing of the competent authorities in the implementation and control of the GPP law, after the adoption of the National GPP Action Plan and the definition of the criteria regarding the public procurement process, the quality of the services will be visibly improved, and within a reasonable time also bringing the optimization of public procurement costs.

Apart from the beneficial implications for the environment, the Romanian legislator also considered the impact on the business environment, explaining that promoting GPP for goods and works / services, a direct consequence, beyond the awareness about the importance of this field - from public bodies to consumers, is the development of the SME business. It was also not considered unimportant that one of the aims of the GPP is to improve the practice of "bio" agriculture, determining the emergence of "new jobs, especially in the rural environment, thus contributing to the revitalization of the rural area" (Cazan, 2014).

Finally, from the point of view of the consumer' behavior, it is estimated that as things progress in the matter of GPP, they will become increasingly aware that, by focusing on ecological goods, the favorable consequences on their health and quality of life, in general, would soon appear.

\subsection{Characterization of the special legal source for the regulation of GPP in the national public sector: sluggishness, loopholes, post-adoption deadlocks}

Introduced in the legislative circuit since 2014, as a legislative initiative of the Executive, the Draft Law on Green Public Procurement would be adopted only after two years. The sluggishness was exclusively related to the parliamentary procedures, but even so it was considered that this normative act represented "an important step towards the adherence to the EU environmental policy, which has its source in the Treaty on the functioning of the EU' (Center of Excellence in Public Procurement, 2019). 
If the objective of the law is "to establish the legal framework for conducting green public procurement in Romania", its purpose is given, among others, by the following: "(i) promoting environmental protection and sustainable development; (ii) promoting sustainable consumption and production, as well as resource efficiency; (iii) encouraging the development and implementation of clean and environmentally friendly technologies; (iv) promoting social progress that favors economic development; (v) ensuring the efficient use of the funds, by promoting products, services and works with a minimal impact on the environment (...)" (Parliament of Romania, 2016).

By intending to clarify some terms and expressions used in its text, the law gives extensive meanings to what the following mean: contracting authority, green public procurement, green public procurement contract, target and European ecological label. Furthermore, starting from the meaning of the notion "contracting authority", we understand that the respective law does not apply only in the case of acquisitions made by public sector or budgetary entities, but also in other multiple situations where subjects belong to private law.

In this sense, reference is made to art. 8 of the Government Emergency Ordinance no. $34 / 2006$, repealed within one month from the appearance of the Law on green public procurement, by Law no. 98 regarding public procurement, which attracts major difficulties in implementation. Moreover, starting from this fact, the specialists claim that "although Law 69/2016 is in force at the present, one day before its entry into force it became impossible to be implemented and was abandoned - due to the reason stated above (Authors' Note)" (Center of Excellence in Public Procurement, 2019).

However, adopted in close connection with the Government Emergency Ordinance no. $34 / 2006$, it was also obligatory for any state body or of another type set up to satisfy general interest needs (if financed, in the majority, by another public law body, or subordinated / subject to the control of another public law body). Also included here are the entities "that have in the composition of the board of directors (...) more than half of the members appointed by a public law body". It is subject to the rules in the field of public procurement also the development of a project within a public-public partnership, as well as any association formed by one or more contracting authorities of public nature.

In the chapter on the provisions applicable to green public procurement, the Law on green public procurement gives to the Ministry of the Environment "the responsibility for the elaboration of the national policy in the field of green public procurement, as well as of the national green public procurement Plan". This last document refers to the binding multiannual targets for GPP, which must be respected by the contracting authorities. The respective authorities award green public procurement contracts, establishing, through the related documentation, environmental protection criteria, whose form is strictly stipulated by the law (Art. 4).

According to the same article (para. 3), any "contracting authority defines and applies the technical specifications describing the object of the contract or parts thereof, specifications that refer to compliance with systems, standards and / or performance levels with an impact on environmental protection, promoting sustainable development by improving the quality of services, their efficiency and optimizing costs, by referring to systems, standards and technical prescriptions that refer to either: a) the EU eco-labeling system; b) the European Commission specific criteria regarding green public procurement; c) the EU criteria regarding ecological production and labeling of ecological products in the field of agriculture and food". 
In the chapter regarding competent authorities, the law in question obligated the Ministry of the Environment, together with ANAP, that within six months from its adoption "to elaborate a guide containing minimum criteria regarding the protection of the environment for groups of products and services, as well as standard specifications" (Art. 5). Later, the same ministry is obligated to establish the National GPP Action Plan, but not later than October 31 of the following year.

The mentioned chapter also refers to the responsibilities of the operator of the Electronic Public Procurement System (SEAP) (Art. 6), as well as to the responsibilities of the contracting authorities in the implementation of the National GPP Action Plan.

The final chapter of the law is the one regarding the sanctions that can be executed by ANAP, considered by specialists as "negative incentives", if deviations from the norm are observed following the observation of the green public procurement contracts' awarding process. According to Art. 9, para. 1 "The following facts constitute a contravention and are sanctioned with a fine from 10,000 lei to 35,000 lei: a) failure to comply with the targets set in the National GPP Action Plan; b) the contracting authorities' failure to complete The Green Public Procurement Plan Form/APV when the awarding notice is published in the SEAP; c) not transmitting by the contracting authorities of the completed APV Report, by March 1 of the year following the one in which the monitoring was carried out".

According to the authors, the Law no. 69/2016 regarding green public procurement may be appreciated as a qualitative/efficient normative text only at the time of the drafting of the project (2014). The long period of time (two years) elapsed during the parliamentary procedures until the adoption (2016) made it inoperable. The reason is that near the moment when it was to enter into force, the Government Emergency Ordinance no. $34 / 2006$ was repealed, and the law we have analyzed was based massively on those provisions.

Adding more sluggishness (this time at the Executive level) we also had to deal with certain post-adoption deadlocks, generating inefficiency. The guide that contains the minimum criteria regarding the environmental protection for groups of products and services, as well as standard specifications, was published in the Official Gazette no. 954 of November 12, 2018 (Ministry of the Environment, 2018), two and a half years after the entry into force of Law no. 69/2016. This happened even though the legal deadline was six months from the adoption of Law 69/2016, i.e., and the respective guide should have been published by October 25, 2016.

Another chain-reaction consequence, given the context, is the lack of elaboration and publication by the Ministry of the Environment of the National GPP Plan in none of the 2016-2018 years, although the legal obligation was for it to be finalized before October 31 st of the following year.

Considering these deficiencies observed by the authors regarding the regulatory framework applicable to GPP at national level, we consider that a first measure that is required for correcting them is the correlation of all the legislative texts regarding the public procurement system as a whole. In this regard, the Romanian legislator must achieve the harmonization of the special law, to which we have previously referred, with the provisions of Law no. 98/2016 on public procurement, Law no. 99/2016 on public sector procurement and Law no. 100/2016 on the concessions of works and services. 


\section{Conclusions}

The concluding part of our paper could be focused on two ideas. Firstly, as is apparent from the first part of this approach, the concerns regarding the consolidation / efficiency of the GPP system have been given precedence - at EU level and, implicitly, the Member States, and tends to become permanent. Moreover, we note the intensification of the politicalinstitutional efforts in this regard, given the importance that is given today, worldwide, to the issues of environmental protection and sustainable development.

This scientific research confirms the need to pay maximum attention to the GPP problem, for the reasons we referred to in the paper, in line with our wide review of the specialized literature. Incidentally, a clear institutional framework has been adopted at EU level, containing norms meant to bring significant improvements to the above-mentioned plan, which have been predominantly transposed at Member States' level. However, as we have found by studying the reports of the relevant institutions, the margins of expectation are still high regarding the actual achievements. Secondly, when we discuss the issues related to the elaboration and implementation of national legal instruments aimed at stimulating GPP, we come up with a whole series of critical issues. In a nutshell, we find that these instruments have not in the least demonstrated their efficiency in stimulating green procurement in the public sector.

The authors' characterization of the special legal source intended for the regulation of GPP in the national public sector highlighted the sluggishness in adoption - especially when it comes to the elaboration of secondary and tertiary legislation, the normative text loopholes and the post-adoption deadlocks that have occurred in the last five years (2014-2019). Moreover, with its explanations residing in the same area, another finding of ours is that the GPP Law has proved to be ineffective since its adoption more than three years ago. This is also one of the major reasons why it is appreciated today that Romania is below the expectations regarding GPP.

We also find post-adoption deadlocks, delays in the development of secondary and tertiary legislation: the guide containing the minimum criteria for environmental protection and the standard specifications was published with a delay of 2.5 years, and until the date of this paper, the National GPP Action Plan has not been published by the Ministry of the Environment, not even as a project, although a first mandatory deadline was October 2016, etc.

Obviously, the authors did not intend to offer punctual solutions, but the examinations carried out entitle them to state that these can only come from legislative changes, in accordance with the best practices of the advanced states and considering the national specificity.

\section{References}

Ajani, G., 2008. A Better Coherence of EU Private Law and Multilingualism. In: R. Schulze ed., 2008. Common Frame of Reference and Existing EC Contract Law. Munchen: Sellier.

Aldenius, M. and Khan, J., 2017. Strategic use of Green Public Procurement in the bus sector: challenges and opportunities. J. Clean. Prod., [e-journal] 164, pp. 250-257. doi:10.1016/j.jclepro.2017.06.196.

Appolloni, A., Sun, H., Jia, F. and Li, X., 2014. Green Procurement in the private sector: A state of the art review between 1996 and 2013. J. Clean. Prod., [e-journal] 85, pp. 122-133. doi:10.1016/j.jclepro.2014.08.106. 
Arrowsmith, S. and Kunzlik, P., 2009. Social and environmental Policies in EC Procurement Law. Cambridge: Cambridge University Press.

Bauer, B., Christensen, J., Christensen, K., Dyekjær-Hansen, T. and Bode, I., 2009. Benefits of Green Public Procurement. Tema Nord 2009:593. Copenhagen: Nordic Council of Ministers.

Bostan, I., Burciu, A. and Condrea, P., 2010. Trends of the communitarian cohesion policies and advertising for eco-investments. Environ Eng Manag J, 9(6), pp.847-851.

Bovis, C.H., 2007. EU Public Procurement Law. Cheltenham: Elgar.

Brammer, S. and Walker, H., 2011. Sustainable procurement in the public sector: an international comparative study. Int. J. Operations Prod. Manag., 31(4), pp.452-476.

Caranta, R. and Trybus, M. eds., 2010. The Law of Green and Social Procurement in Europe. Copenhagen: DJØF Publishing.

Cazan, R., 2014. Achiziţii publice ecologice în România. Protecţia mediului prin cheltuieli publice responsabile. București: ECOPOLIS [online] Available at: $<$ https://www.ecopolis.org.ro/media/Achizitii\%20publice\%20ecologice\%20in\%20roma nia-final.pdf> [Accessed 2 May 2019].

Călinoiu, A., 2018. Instituţiile publice din România vor fi obligate să facă achiziţii verzi. Telegrama, 27 Iunie, [online] Available at: $<$ https://www.telegrama.ro/actualitate/item/ 70889-proiect-institutiile-publice-din-romania-vor-fi-obligate-sa-faca-achizitiiverzi.html> [Accessed 27 May 2019].

Centrul de Excelență în Achizitii Publice, 2019. Ce se întâmplă cu Legea 69/2016 privind achizițile publice verzi?, [online] Available at: $<$ https://www.linkedin.com/pulse/ce-se\%C3\%AEnt\%C3\%A2mpl\%C4\%83-cu-legea-692016-privind-achizi\%C5\%A3iile> [Accessed 11 July 2019].

Cheng, W., Appolloni, A., D’Amato, A. and Zhu, Q., 2018. Green Public Procurement, missing concepts and future trend - A critical review. J. Clean. Prod., [e-journal] 176, pp.770-784. doi:10.1016/j.jclepro.2017.12.027.

Commission of The European Communities, 2005. Communication to The Spring European Council, Working together for growth and jobs (...),\{SEC(2005)192\}, \{SEC(2005)193\}, Brussels, [online] Available at: <https://www.fonduri-structurale.ro/ Document_Files//strategialisabona/00000070/8kox1_Strategia_Lisabona_revizuita_eng. pdf> [Accessed 4 May 2019].

Davies, A., 2011. The law of green and social procurement in Europe. Eur. Law Rev., 36, pp.762-765.

Dragos, D.C. and Neamtu, B., 2013. Sustainable Public Procurement: Life Cycle Costing (LCC) in the New EU Directive Proposal. European Public Procurement and PPP Law Review, [e-journal] 1, pp.19-30. doi:10.21552/EPPPL/2013/1/159.

ECAP, 2018. Embedding Circular Procurement in purchasing of workwear. Project code: LIFE14, ENV/UK/00257, [online] Available at: <http://www.ecap.eu.com/wp-content/ uploads/2018/07/Embedding-Circular-Procurement-in-purchasing-of-workwear.pdf> [Accessed 27 April 2019].

European Commission, 2001. Comunicarea interpretativă a Comisiei privind dreptul comunitar aplicabil contractelor de achiziţii publice și posibilităţile de a integra aspecte sociale în respectivele contracte, COM (2001) 566 final, [online] Available at: $<$ https://ec.europa.eu/transparency/regdoc/rep/1/2001/EN/1-2001-566-EN-F1-1.Pdf> [Accessed 9 June 2019].

European Commission, 2007. Achiziţii ecologice. Luxemburg: Oficiul pentru Publicaţii Oficiale ale Comunităţilor Europene. 
European Commission, 2008. Achiziții publice pentru îmbunătățirea condițiilor de mediu. Bruxelles: COM(2008)400 final, [online] Available at: <http://eur-lex.europa.eu/ LexUriServ/LexUriServ.do?uri=COM:2008:0400:FIN:ro:PDF> [Accessed 22 April 2019].

European Commission, 2009. Instrumente de formare - Modulul 1. Un plan de Acțiune pentru Achiziții Publice Ecologice (Ciclul "Deming"), [online] Available at: $<$ https://www.fonduri-structurale.ro/Document_Files//Evenimente/00005751/ r2dy6_Program\%20Conferinta.pdf> [Accessed 27 May 2019].

European Comission, 2010. Green Public Procurement. [online] Available at: $<$ https://ec.europa.eu/environment/gpp/pdf/brochure.pdf $>$ [Accessed 27 April 2019].

European Commission, 2016a. Buying green! A handbook on green public procurement, [online] Available at: <http://sustainable-procurement.org/fileadmin/user_upload/ layout/Documents/Buying-Green-Handbook-3rd-Edition.pdf> [Accessed 5 May 2019].

European Commission, 2016b. Sustainable procurement under The Procurement Directives [online] Available at: <http://sustainable-procurement.org/eu-policy $>$ [Accessed 7 May 2019].

European Commission, 2019. Evaluarea punerii în aplicare a politicilor de mediu ale UE. Raport de țară - România, [online] Available at: <https://ec.europa.eu/environment/ eir/pdf/report_ro_ro.pdf> [Accessed 11 June 2019].

European Council, 2001. The Gothenburg European Council COM(2001) 264 final.

European Parliament, 2004a. Directive 2004/17/EC of the European Parliament and of the Council of 31 March 2004 coordinating the procurement procedures of entities operating in the water, energy, transport and postal services sectors.

European Parliament, 2004b. Directive 2004/18/EC of the European Parliament and of the Council of 31 March 2004 on the coordination of procedures for the award of public works contracts, public supply contracts and public service contracts.

Fuentes-Bargues, J.L., Ferrer-Gisbert, P.S., González-Cruz, M.C. and Jose Bastante-Ceca, M., 2019. Green Public Procurement at a Regional Level. Case Study: The Valencia Region of Spain. Int. J. Environ. Res. Public Health, [e-journal] 16(16), p.2936. doi:10.3390/ijerph16162936.

Giurca, I. and Giurca, I., 2010. Green public procurement regarding central heating systems. Management şi Inginerie Economică, 9(1(35)), pp.189-196.

Government of Romania, 2006. Ordonanța de urgență no. 34 privind atribuirea contractelor de achiziţie publică.

Government of Romania, 2008. Hotărârea no. 1460 pentru aprobarea Strategiei naţionale pentru dezvoltare durabilă. Orizonturi 2013-2020-2030.

Government of Romania, 2014. Expunere de motive la Legea privind achizițiile publice verzi, [online] Available at: <http://mmediu.ro/new/wp-content/uploads/2014/08/201408-26_Expun_motiv_Lege-APV.pdf> [Accessed 12 May 2019].

Igarashi, M., De Boer, L. and Michelsen, O., 2015. Investigating the anatomy of supplier selection in green public procurement. J. Clean. Prod., [e-journal] 108, pp.442-450. doi:10.1016/j.jclepro.2015.08.010.

Kaukewitsch, R., 2018. EU Green Public Procurement (GPP) Policy, Enhance thematic workshop. EC- Environment Directorate-General, [online] Available at: $<$ https://www.interregeurope.eu/fileadmin/user_upload/tx_tevprojects/library/file_1520 607101.pdf > [Accessed 22 April 2019].

Leica, S.C., Radu, R.I. and Mihai, I.O., 2017. Sustainability of the Public Acquisitions System in Romania in the Process of Transition to a Green Economy. Ovidius University Annals. Economic Sciences Series, XVII(1), pp.524-529. 
Lundberg, S. and Marklund, P.O., 2013. Green public procurement as an environmental policy instrument: cost effectiveness. Environ. Econ., 4(4), pp.75-83.

Lundberg, S. and Marklund, P.O., 2017. Influence of green public procurement on bids and prices. [online] Available at: <https://www.nhh.no/globalassets/departments/businessand-management-science/seminars/2016-spring/120516.pdf > [Accessed 12 May 2019].

Lundberg, S., Marklund, P.O. and Stromback, E., 2016. Is environmental policy by public procurement effective? Public Finance Review, 44(4), pp.478-499.

Malatinec, T., 2017. Legislative framework of green public procurement and Europeanisation of the Slovak practice. Juridical Tribune, 7(Sp. Issue), pp.95-107.

McCrudden, 2007. Buying social justice: Equality, Government Procurement and Legal Change. Oxford: OUP.

Michelsen, O. and De Boer, L., 2009. Green procurement in Norway: A survey of practices at the municipal and county level. J. Environ. Manag., [e-journal] 91(1), pp.160-167. doi:10.1016/j.jenvman.2009.08.001.

Ministry of the Environment, 2018. Order of the Minister of the Environment no. 1068/1652/2018 for approval of the Green Procurement Guide.

MSDEC, 2018. Green public procurement national action plan 2019-2025. Ministry for the Environment, Sustainable Development and Climate Change of Malta, [online] Available at: <https://msdec.gov.mt/en/decc/Documents/environment/gpp/2019/ secondNap/gppSecondNap.pdf> [Accessed 29 May 2019].

Nikolaou, I.E. and Loizou, C., 2015. The Green Public Procurement in the midst of the economic crisis: Is it a suitable policy tool? J. Integr. Environ. Sci., [e-journal] 12(1), pp.49-66. doi:10.1080/1943815X.2014.993657.

Nissinen, A., Parikka-Alhola, K. and Rita, H., 2009. Environmental criteria in the public purchases above the EU threshold values by three Nordic countries: 2003 and 2005 . Ecol. Econ., [e-journal] 68(1), pp.1838-1849. doi:10.1016/j.ecolecon.2008.12.005.

OCDE, 2002. Recommendation of the Council to improve the environmental performance of public procurement C(2002)3, [online] Available at: <http://www.oecd.org> [Accessed 24 April 2018].

ONU, 2015. Transforming our world: the 2030 Agenda for Sustainable Development, [online] Available at: <http://www.un.org/ga/search/view_doc.asp?symbol=A/RES/70/ 1\&Lang=E > [Accessed 29 July 2019].

Oruezabala, G. and Rico, J.C., 2012. The Impact of Sustainable Public Procurement on Supplier Management - The Case of French Public Hospitals. Industrial Marketing Management, 41(4), pp.573-580.

Palmujoki, A., Parikka-Alhola, K. and Ekroos, A., 2010. Green Public Procurement: Analysis on the Use of Environmental Criteria in Contracts. Rev. Eur. Community Int Environ. Law, [e-journal] 19(2), pp.250-262. doi:10.1111/j.1467-9388.2010.00681.x.

Parliament of Romania, 2012. Government Program 2013-2016 approved by Parliament's Decision no. 45/2012, [online] Available at: <http://www.cdep.ro/proiecte/2015/400/ 60/3/em586.pdf> [Accessed 4 July 2019].

Parliament of Romania, 2015. Reason for the Draft Law on Green Public Procurement, [online] Available at: <http://www.cdep.ro/proiecte/2015/400/60/3/em586.pdf> [Accessed 24 June 2019].

Parliament of Romania, 2016. Law no. 69 on green public procurement, Available at: $<$ http://www.mmediu.ro/app/webroot/uploads/files/2016-08-04_LEGE_Nr_69_din_ 2016.pdf> [Accessed 5 July 2019].

Potočnik, J., 2016. Green Public Procurement, [online] Available at: <https://ec.europa.eu/ environment/gpp/index_en.htm> [Accessed 2 June 2019]. 
Preda, I. and Popescu, D.I., 2019. Considerations on Green Public Procurement of Coaches. Journal of Eastern Europe Research in Business and Economics, [e-journal]. doi:10.5171/2019.139043.

Preda, I. and Simion, C.P., 2019. The Evaluation of Life Cycle Cost within Green Public Procurement of Sedans in Romania [online] Available at: $<$ https://ibima.org/acceptedpaper/the-evaluation-of-life-cycle-cost-within-green-public-procurement-of-sedans-inromania> [Accessed 3 May 2019].

Preuss, L., 2009. Addressing sustainable development through public procurement: The case of local government. Supply Chain Manag. Int. J., [e-journal] 14(3), pp.213-223. doi:10.1108/13598540910954557.

Smith, C. and Terman, J., 2016. Overcoming the Barriers to Green Procurement in the County: Interest Groups and Administrative Professionalism. Journal of Public Procurement, [e-journal] 16(3), pp.259-285. doi:10.1108/JOPP-16-03-2016-B001.

Staropoli, C., 2017. GPP - Public Procurement and Energy Transition Science. [online] Available at: <https://www.webssa.net/files/slides_coursegpp-2017.pdf > [Accessed 21 May 2019].

Tessema, F. and Marsille, C., 2009. Practical Insights and Illustrative Examples on Sustainable Public Procurement. Case Studies from Europe. SuPP-Urb-China Paper, No. 3_EN/CN.CSCP. Wuppertal, Germany.

Testa, F., Annunziata, E., Iraldo, F. and Frey, M., 2016a. Drawbacks and opportunities of green public procurement: An effective tool for sustainable production. J. Clean Prod., [e-journal] 112, pp.1893-1900. doi:10.1016/j.jclepro.2014.09.092.

Testa, F., Grappio, P., Gusmerotti, N.M., Iraldo, F. and Frey, M., 2016b. Examining Green Public Procurement using content analysis: existing difficulties for procurers and useful recommendations. Environ. Dev. Sustain., [e-journal] 18(1), pp.197-219. doi:10.1007/s10668-015-9634-1.

Trindade, P.C., Antunes, P. and Partidário, P., 2018. SPP Toolbox: Supporting Sustainable Public Procurement in the Context of Socio-Technical Transitions. Sustainability, [ejournal] 10(1), p.67. doi:10.3390/su10010067.

Varnäs, A., Balfors, B. and Faith-Ell, C. 2009. Environmental consideration in procurement of construction contracts: Current practice, problems and opportunities in green procurement in the Swedish construction industry. J. Clean. Prod., [e-journal] 17(13), pp.1214-1222. doi:10.1016/j.jclepro.2009.04.001.

Walter, H. and Brammer, S., 2009. Sustainable procurement in the United Kingdom public sector. Supply Chain Manag, 14(2), pp.128-137.

WSSD, 2002. World Summit on Sustainable Development. [online] Available at: $<$ http://www.un.org/esa/sustdev/documents/WSSD_POI_PD/English/POIToc.htm> [Accessed 25 April 2019].

Xu, S., Chu, C., Ju, M. and Shao, C., 2016. System Establishment and Method Application for Quantitatively Evaluating the Green Degree of the Products in Green Public Procurement. Sustainability, [e-journal] 8, p.941. doi:10.3390/su8090941.

Zhu, Q., Geng, Y. and Sarkis, J., 2013. Motivating green public procurement in China: An individual level perspective. J. Environ. Manag., [e-journal] 126, pp.85-95. DOI: 10.1016/j.jenvman.2013.04.009. 